\title{
Pediatric hydrocephalus: systematic literature review and evidence-based guidelines. Part 7: Antibiotic-impregnated shunt systems versus conventional shunts in children: a systematic review and meta-analysis
}

\author{
Paul Klimo Jr., M.D., M.P.H., ${ }^{1-3}$ Clinton J. Thompson, Ph.D., ${ }^{4}$ Lissa C. Baird, M.D., ${ }^{4}$ \\ ANd Ann Marie Flannery, M.D. 5 \\ ${ }^{1}$ Semmes-Murphey Neurologic \& Spine Institute; ${ }^{2}$ Department of Neurosurgery, University of Tennessee \\ Health Science Center; ${ }^{3}$ Le Bonheur Children's Hospital, Memphis, Tennessee; ${ }^{4}$ School of Public Health and \\ Health Services, The George Washington University, Washington, DC; and ${ }^{5}$ Department of Neurological \\ Surgery, Saint Louis University, St. Louis, Missouri
}

Object. The objective of this systematic review and meta-analysis was to answer the following question: Are antibiotic-impregnated shunts (AISs) superior to standard shunts (SSs) at reducing the risk of shunt infection in pediatric patients with hydrocephalus?

Methods. Both the US National Library of Medicine PubMed/MEDLINE database and the Cochrane Database of Systematic Reviews were queried using MeSH headings and key words relevant to AIS use in children. Abstracts were reviewed, after which studies meeting the inclusion criteria were selected. An evidentiary table was assembled summarizing the studies and the quality of their evidence (Classes I-III). A meta-analysis was conducted using a random-effects model to calculate a cumulative estimate of treatment effect using risk ratio (RR). Heterogeneity was assessed using the chi-square and $\mathrm{I}^{2}$ statistics. Based on the quality of the literature and the result of the meta-analysis, a recommendation was rendered (Level I, II, or III).

Results. Six studies, all Class III, met our inclusion criteria. All but one study focused on a retrospective cohort and all but one were conducted at a single institution. Four of the studies failed to demonstrate a lowered infection rate with the use of an AIS. However, when the data from individual studies were pooled together, the infection rate in the AIS group was 5.5\% compared with $8.6 \%$ in the SS group. Using a random-effects model, the cumulative RR was $0.51(95 \%$ CI $0.29-0.89, \mathrm{p}<0.001)$, indicating that a shunt infection was 1.96 times more likely in patients who received an SS.

Conclusions. We recommend AIS tubing because of the associated lower risk of shunt infection compared to the use of conventional silicone hardware (quality of evidence: Class III; strength of recommendation: Level III).

RECOMMENDATION: Antibiotic-impregnated shunt (AIS) tubing may be associated with a lower risk of shunt infection compared with conventional silicone hardware and thus is an option for children who require placement of a shunt. Strength of ReCOMmendation: Level III, unclear degree of clinical certainty.

(http://thejns.org/doi/abs/10.3171/2014.7.PEDS14327)

KEY WORDS $\bullet \quad$ antibiotic-impregnated shunt $\bullet$ shunt $\bullet$ cerebrospinal fluid
infection $\bullet \quad$ pediatric patient $\bullet \quad$ meta-analysis
practice guidelines

$\mathrm{P}$ REVENTION of shunt infection is a priority for neurosurgeons, especially when treating pediatric patients. Infection can cause shunt malfunction with all the potential consequences of a nonfunctioning shunt. Shunt infection can lead to scarring and loculation of the ventricles, increasing the complexity of the patient's hydrocephalus, and it may result in a lower intelligence

\footnotetext{
Abbreviations used in this paper: AIS = antibiotic-impregnated shunt; AANS = American Association of Neurological Surgeons; $\mathrm{CNS}=$ Congress of Neurological Surgeons; $\mathrm{RR}=$ risk ratio; $\mathrm{SS}=$ standard shunt.
}

quotient, increased risk of seizures, and psychomotor retardation. $8,26,34,54,55$ Treatment of shunt infections is costly, estimated to be upwards of $\$ 50,000$ per infection in the United States, making it one of the most costly implantrelated infections. ${ }^{12}$

The identification of modifiable risk factors or interventions to lower the risk of a shunt infection has been the topic of active research for many years. Identified factors include the duration of surgery, ${ }^{32,41}$ the skill and experience of the treating neurosurgeon; $;, 10,29$ the number of personnel in the operating room; $9,30,39$ and the use of hair shaving, ${ }^{25,41}$ prophylactic systemic antibiotics, ${ }^{22,42,56}$ intrathecal 
antibiotics, ${ }^{40}$ wound irrigation, ${ }^{23}$ antibiotic-impregnated sutures, ${ }^{47,52}$ and double gloving ${ }^{43}$ (or inadvertent exposure of the shunt to breached surgical gloves). ${ }^{33}$ Antibiotic-impregnated Silastic catheters were first introduced by Roger Bayston in 1977; they were considered more specifically with shunts in $1989,{ }^{5}$ but did not become available for clinical use in the United States until about 10 years ago. The antibiotic-impregnated shunt (AIS) systems currently on the market contain $0.054 \%$ rifampin and $0.15 \%$ clindamycin, which target the most common pathogens: Staphylococcus epidermidis and Staphylococcus aureus. Although rifampin and clindamycin do not reduce bacterial adherence, this combination of antibiotics kills bacteria and has been shown to prevent colonization for up to 56 days in in vitro studies and up to 127 days in vivo., ${ }^{4,6,37}$

Many studies have evaluated the efficacy of AISs compared with standard shunts (SSs) in the prevention of shunt infections, including two recent systematic reviews and meta-analyses. ${ }^{1,2,15,17,19-21,24,27,28,31,35,36,38,44,45,50,51,53}$ The purpose of this evidence-based review is to examine data on the use of AISs and SSs and compare these treatments in the prevention of shunt infections in the pediatric population.

\section{Methods}

\section{Search Terms}

We searched the US National Library of Medicine PubMed/MEDLINE database and the Cochrane Database of Systematic Reviews for the period January 1966 through March 2012 using the following MeSH subject headings: ("cerebrospinal fluid shunts" OR ("cerebrospinal fluid" AND (shunt* OR catheter*)) OR "shunt system") AND ("antibiotic-impregnated" OR (antibiotic AND impregnated)) AND infection.

\section{Search Strategy}

We reviewed the titles and abstracts of the papers we retrieved with attention to those titles addressing the rate of shunt infection in patients treated with AISs compared with those treated with SSs. Uncontrolled studies were excluded, as were studies that evaluated antimicrobial shunts unavailable in the US market. In all papers, we required that the authors state that the only variable that changed was the type of shunt implanted; all other aspects of the surgery and technique needed to remain unchanged.

\section{Meta-Analysis}

For each study, we identified the number of infections resulting from implantation of SSs and AISs and then computed the risk of an infection associated with AISs relative to that associated with SSs, yielding a risk ratio (RR). An RR less than 1 is indicative of protection against infection for the AIS. The overall RR was computed using the method of DerSimonian and Laird. ${ }^{14}$

We conducted a random-effects meta-analysis of the selected studies. A random-effects model-as opposed to a fixed-effects model-does not assume that the measure of association (that is, RR) is uniform across strata (that is, among studies) and, consequently, yields a more con- servative estimate of the effect. We assessed heterogeneity by way of the chi-square test of heterogeneity and the $\mathrm{I}^{2}$ statistic, in which the former returns a chi-square distributed test statistic and corresponding $\mathrm{p}$ value and the latter returns a value bound between $0 \%$ and $100 \%$, with higher values denoting increasing heterogeneity. We regarded a chi-square test of heterogeneity $\mathrm{p}$ value less than alpha $=0.10$ and an $\mathrm{I}^{2}$ value in the range of $30 \%$ to $60 \%$ as suggestive of moderate heterogeneity. ${ }^{11,13}$ An examination of publication bias was not conducted since the number of studies included in this analysis was not large enough to provide adequate power (i.e., fewer than 10 studies).

\section{Search Results}

Our search returned 41 articles; another 3 articles were found from an examination of the articles' bibliographies (Fig. 1). Nineteen full-length papers were reviewed, 13 of which were rejected for the following reasons: studies enrolled either adults only or enrolled mixed populations, but separate results for children were not provided, $1,19,20,36,38,44,45,51$ or studies contained patient data that had also been reported in separate publications. ${ }^{3,16,47-49}$ In fact, 1 group of researchers published no less than 9 papers on AISs that included patients from overlapping time periods. $3,17,18,35,36,47-50$ Therefore, 6 articles satisfied inclusion for this systematic review and meta-analysis (Table 1). $2,15,24,27,28,50$

\section{Results}

The review process identified no papers providing Class I or II data specifically addressing the issue of shunt infection and the use of AISs compared with SSs in children. The 6 articles that satisfied our entry criteria were all Class III cohort studies, all but one of which were conducted within a single institution. The primary outcome of interest-shunt infection-was defined by authors of individual studies, but in general, it was a patient who underwent a recent shunt surgery and subsequently developed signs and symptoms of a shunt malfunction or an infection with an organism cultured from CSF, the shunt apparatus, purulence from the shunt wound(s), or abdominal fluid/pseudocyst. Some investigators also considered a patient to have an infection if there were highly suggestive findings such as fever, redness along the shunt, or CSF pleocytosis in the absence of a positive culture. Overall, 2 studies produced findings that AISs are protective against shunt infection, whereas the remaining studies did not.

Sciubba et al..$^{50}$ reported one of the earliest large series comparing AISs with SSs in a pediatric population. During an 18-month period, 208 SSs were placed; this was followed by another 18-month period during which AISs were used 145 times. The AIS patient group was younger, more frequently premature, and thus had a greater incidence of intracranial hemorrhage as the cause of hydrocephalus. The primary outcome was the development of a shunt infection, defined as clinical suspicion (fever, increased white blood cell count, and/or wound breakdown involving the shunt) with positive cultures from CSF and/or hardware. Patients who received AIS 
Part 7: AIS systems versus conventional shunts in children

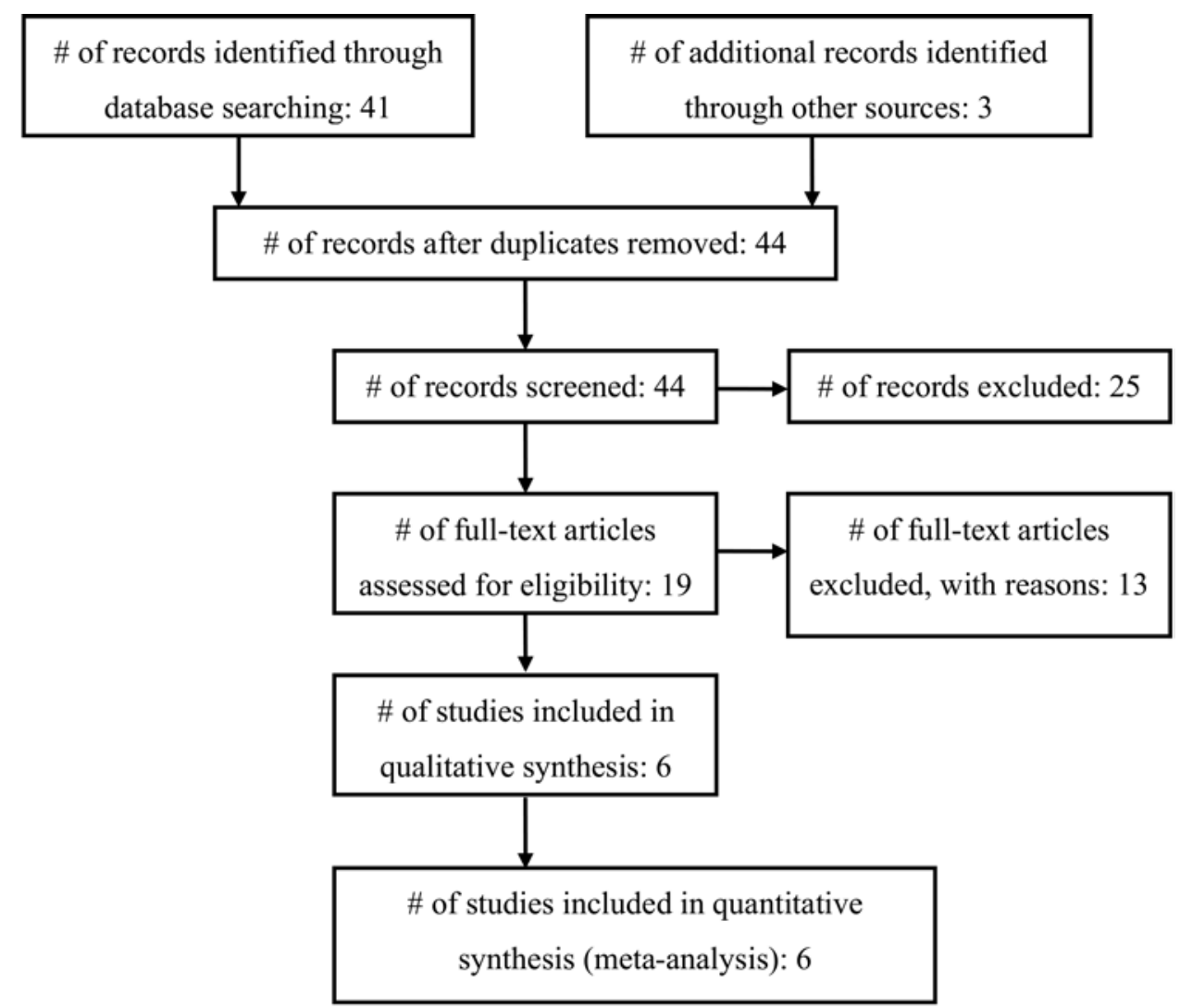

FIG. 1. Flowchart showing the process involved in identifying relevant literature.

catheters had significantly fewer shunt infections: 2 patients $(1.4 \%)$ with antibiotic-impregnated catheters within the 6-month follow-up period compared with 25 patients (12\%) with non-antibiotic-impregnated catheters. After we adjusted for intercohort differences in primary placement compared with shunt revision, prematurity, and posthemorrhagic hydrocephalus, we found AIS catheters to be independently associated with a 2.4 -fold decreased likelihood of shunt infection.
Aryan et al. ${ }^{2}$ detailed their 1-year experience using the Bactiseal system (Codman, Johnson \& Johnson). Although the rate of shunt infection was lower in the Bactiseal group (1 of 32 [3.1\%]) compared with the standard group (7 of $46[15.2 \%]$ ), the difference was not statistically significant $(\mathrm{p}=0.09)$. Kan and $\mathrm{Kestler}^{27}$ reported on a similar retrospective cohort in which 80 consecutive patients received the Bactiseal shunt and were compared with an earlier group of 80 patients who had received an

TABLE 1: Antibiotic-impregnated shunt systems versus conventional shunt systems: summary of evidence

\begin{tabular}{|c|c|c|c|}
\hline Authors \& Year & Study Description & Data Class, Quality, \& Reasons & Results* \& Conclusions \\
\hline $\begin{array}{l}\text { Kandasamy et } \\
\text { al., } 2011\end{array}$ & Ambispective, multiinstitutional. & $\begin{array}{l}\text { Class III } \\
\text { Ambispective cohort w/ historical controls. }\end{array}$ & $\begin{array}{l}\text { AIS Group: } 30 \text { of } 581 \text { (5.2\%); SS Group: } 155 \text { of } 1963 \\
(7.9 \%) \text {. AIS reduced shunt infection rate. }\end{array}$ \\
\hline $\begin{array}{l}\text { Eymann et al., } \\
2008\end{array}$ & Retrospective, single institution. & $\begin{array}{l}\text { Class III } \\
\text { Retrospective cohort. }\end{array}$ & $\begin{array}{l}\text { AIS Group: } 1 \text { of } 26(3.8 \%) \text {; SS Group: } 3 \text { of } 22 \\
(13.6 \%) \text {. No statistically significant difference.† }\end{array}$ \\
\hline $\begin{array}{l}\text { Aryan et al., } \\
2005\end{array}$ & Retrospective, single institution. & $\begin{array}{l}\text { Class III } \\
\text { Retrospective cohort. }\end{array}$ & $\begin{array}{l}\text { AIS Group: } 1 \text { of } 32 \text { (3.1\%); SS group: } 7 \text { of } 46 \\
\text { (15.2\%). No statistically significant difference. }\end{array}$ \\
\hline $\begin{array}{l}\text { Hayhurst et al., } \\
2008\end{array}$ & Retrospective, single institution. & $\begin{array}{l}\text { Class III } \\
\text { Historical controls were used. }\end{array}$ & $\begin{array}{l}\text { AIS Group: } 21 \text { of } 214 \text { (9.8\%); SS Group: } 8 \text { of } 77 \\
(10.4 \%) \text {. No statistically significant difference. }\end{array}$ \\
\hline $\begin{array}{l}\text { Kan \& Kestle, } \\
2007\end{array}$ & Retrospective, single institution. & $\begin{array}{l}\text { Class III } \\
\text { Retrospective cohort. }\end{array}$ & $\begin{array}{l}\text { AIS Group: } 4 \text { of } 80(5 \%) \text {; SS Group: } 7 \text { of } 80(8.8 \%) \text {. } \\
\text { No statistically significant difference. }\end{array}$ \\
\hline $\begin{array}{l}\text { Sciubba et al., } \\
2005\end{array}$ & Retrospective, single institution. & $\begin{array}{l}\text { Class III } \\
\text { Retrospective cohort. }\end{array}$ & $\begin{array}{l}\text { AIS Group: } 2 \text { of } 145 \text { (1.4\%); SS Group: } 25 \text { of } 208 \\
(12 \%) \text {. AIS reduced shunt infection rate. }\end{array}$ \\
\hline
\end{tabular}

* Percentages represent per shunt procedure, not per patient.

$\dagger$ Fisher's exact test was used. 
SS. There was no statistically significant difference in the shunt infection rate $(5.0 \%$ vs $8.8 \%$ ), even when the authors controlled for patient age at surgery, type of revision, cause of hydrocephalus, and previous revisions or infections within the past 6 months.

In their retrospective cohort study, Hayhurst and coworkers ${ }^{24}$ looked at 4 groups of patients in whom AISs had been implanted de novo (Group 1), during noninfected revisional surgery (Group 2), and after an external ventricular drain had been replaced by the shunt (sterile CSF [Group 3] and infected CSF [Group 4]). There were 214 shunt procedures performed using the Bactiseal system in 150 children. The historical control group comprised 77 operations in 65 children. Again, there was no statistically significant difference in the infection rate (21 of 214 [9.8\%] in the antibiotic group and 8 of 77 [10.4\%] in the standard group). Although the authors emphasized the difference in the infection rate among neonates $-27 \%$ in the standard group versus $11 \%$ in the antibiotic groupthis difference too was not significant $(p=0.208)$. Eymann et al ${ }^{15}$ presented clinical and cost data for both adult and pediatric patients. Using Fisher's exact test, the pediatric infection rates of $13.6 \%$ in the standard group and $3.8 \%$ in the Bactiseal group were not statistically different. However, when the authors combined both adult and pediatric outcomes, they did find a protective benefit with the Bactiseal system and a net savings of $\$ 51,651$ in the 197 Bactiseal procedures.

The study with the largest number of patients was conducted by Kandasamy et al. ${ }^{28}$ This multicenter study (3 pediatric neurosurgery centers in the United Kingdom) was ambispective: patients treated with AISs were pro- spectively followed, whereas patients treated with SSs at earlier time periods were retrospectively reviewed (historical control). Operations were divided into those that were de novo and those that were clean revisions. There was some intercenter variability in the choice of preoperative antibiotics and surgical technique, but there was no intracenter variability. For example, centers at Leeds and Liverpool used a single dose of cefuroxime, whereas London used flucloxacillin and amikacin. The overall pooled treatment effect estimate statistically favored AISs for de novo and clean revisions combined (the incidence of infection in the AIS Group was 30 of 581 [5.2\%] and that in the SS Group was 155 of 1963 [7.9\%]) as well as for the subgroup of de novo shunts only and the subgroup of children younger than 1 year of age; the pooled treatment effect estimate for clean revisions only did not reach statistical significance.

\section{Meta-Analysis Results}

In total, there were 2396 procedures in which a standard catheter system had been placed and 205 infections occurred, yielding a pooled infection rate of $8.6 \%$. In the AIS population, 59 infections occurred after 1078 shunt operations for an overall infection rate of 5.5\%. Thus, the absolute and relative risk reductions were $3.1 \%$ and $36 \%$, respectively. The overall RR was 0.51 (95\% CI 0.29-0.89, $\mathrm{p}<0.001$ ), making a shunt infection 1.96 times more likely when an SS system is used (Fig. 2). Although the chisquare test did not indicate heterogeneity $(p=0.129)$, the $\mathrm{I}^{2}$ test did show moderate heterogeneity $(41.5 \%)$.

To explore the uncertainty of statistical significance in

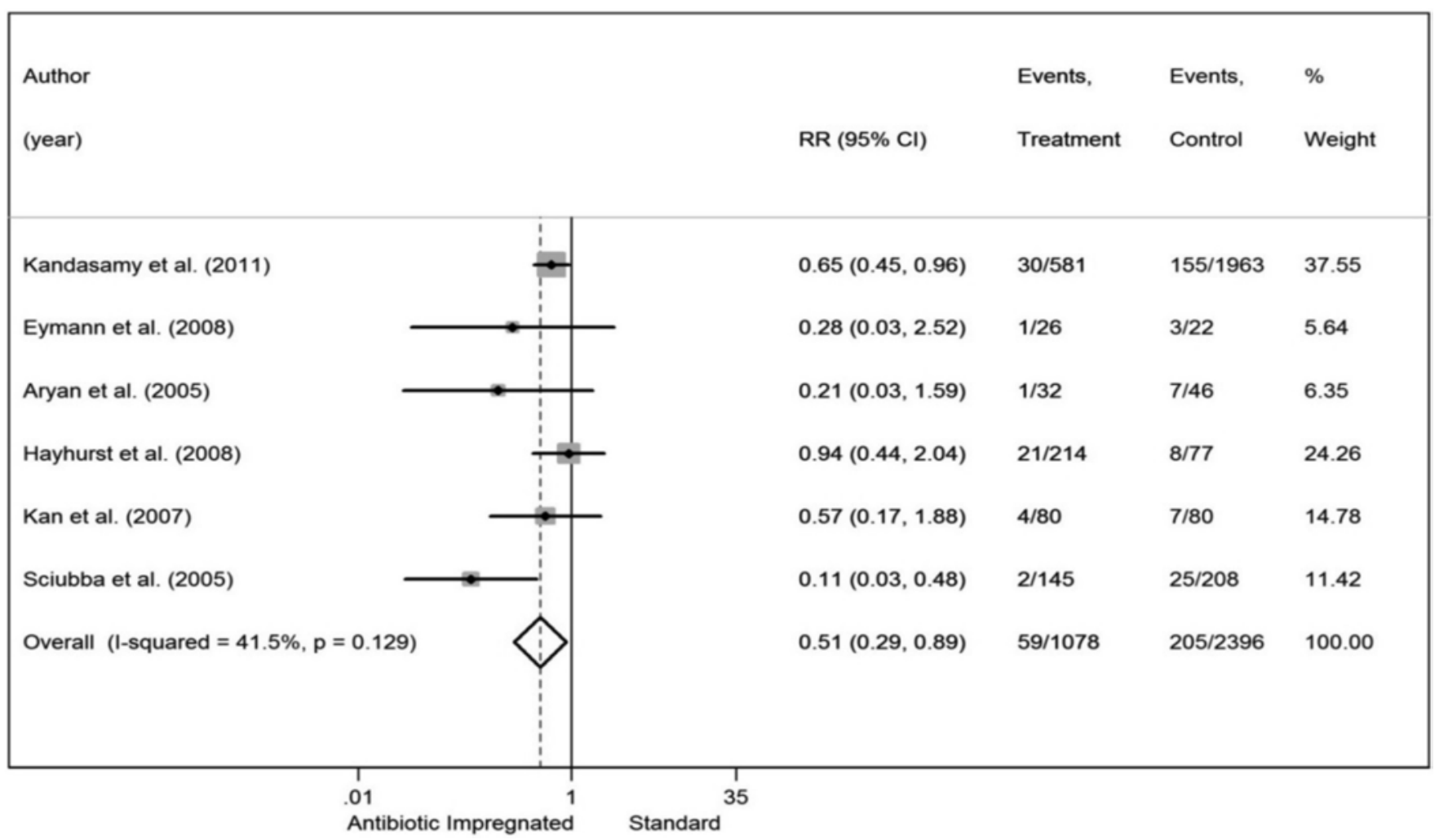

FiG. 2. Forest plot comparing AISs and SSs. 
Part 7: AIS systems versus conventional shunts in children

TABLE 2: Results of the sensitivity analysis: summary of evidence

\begin{tabular}{cccl}
\hline No. of Largest Studies & RR $(95 \% \mathrm{Cl})$ & Heterogeneity $\left(\mathrm{I}^{2}\right)$ & Result \\
\hline All studies (Fig. 1) & $0.51(0.29-0.89)$ & $41.5 \%$ & Statistically significant \\
\hline 5 largest studies & $0.52(0.28-0.95)$ & $50.5 \%$ & Statistically significant \\
\hline largest studies & $0.55(0.29-1.05)$ & $56.5 \%$ & Not significant \\
\hline 3 largest studies & $0.52(0.23-1.20)$ & $71.0 \%$ & Not significant \\
\hline 2 largest studies & $0.31(0.06-1.75)$ & $82.1 \%$ & Not significant \\
\hline
\end{tabular}

the RR meta-analysis, a stepwise sensitivity analysis was performed (Table 2). When subtracting studies from the meta-analysis (and thus reducing the power of the analysis), the effect size remains relatively stable, but confidence intervals widen to the point of statistical nonsignificance. Based on significant findings in large studies comparing AISs with SSs and significant findings in a meta-analysis with a high number of studies, it is likely that the metaanalysis shown in Fig. 2 accurately represents a statistically significant effect in favor of using AISs.

\section{Number Needed to Treat}

There is a certain difficulty with interpreting an RR of 0.51 , in that the number of people who benefited from AIS treatment is masked by the interpretation of an RR (i.e., a " $50 \%$ reduced risk of infection"). In fact the infection rate in the AIS patient group in this meta-analysis was $5.47 \%$ compared with $8.55 \%$ in the SS patient group. These infection rates come close to approximating a "50\% reduced risk of infection."

To better understand the analysis of AISs versus SSs, absolute values calculated as the number of cases needed to treat and the number of infections avoided per 1000 cases treated with AISs were calculated (Table 2). According to the data reported in the literature, for every 24 cases treated with an AIS, 1 infection is prevented. Alternatively, 42 infections are avoided for every 1000 cases treated with AISs. As a convenience, several population infection rates (that is, infection rates unique to particular locations/practices) are presented in Table 3. Not surprisingly, the higher an infection rate in a population, the "better" the AIS becomes at preventing infection.

\section{Conclusions}

ReCommendation: Antibiotic-impregnated shunt (AIS)

TABLE 3: Number of cases needed to treat: summary of evidence

\begin{tabular}{ccc}
\hline $\begin{array}{c}\text { Assumed Population } \\
\text { Infection Rate (\%) }\end{array}$ & $\begin{array}{c}\text { No. of Cases } \\
\text { Needed to Treat }\end{array}$ & $\begin{array}{c}\text { No. of Infections Avoided } \\
\text { per } 1000 \text { Cases Treated } \\
\text { W/ AIS (95\% Cl) }\end{array}$ \\
\hline 5 & 41 & $24(5-35)$ \\
\hline $8.6^{*}$ & 24 & $42(9-60)$ \\
10 & 21 & $49(11-70)$ \\
12.5 & 17 & $61(14-88)$ \\
15 & 14 & $73(16-106)$ \\
\hline
\end{tabular}

* Infection rate found in the present meta-analysis. tubing may be associated with a lower risk of shunt infection compared with conventional silicone hardware and thus is an option for children who require placement of a shunt. Strength of Recommendation: Level III, unclear degree of clinical certainty.

The clinical and financial consequences of a shunt infection are substantial as is the emotional stress borne by patients and their families. Neurosurgeons have evaluated many interventions in the hopes of finding ones that can decrease the risk of developing a shunt infection. Based on the available Class III evidence, we have demonstrated that antibiotic-impregnated shunts (AISs containing rifampin and clindamycin) can lower the shunt infection risk substantially. Although only 2 of the 6 studies that met our inclusion criteria showed a protective benefit with AISs, when the data from all 6 studies were pooled together (meta-analysis), a benefit was shown, with an infection rate almost twice as high in patients receiving a standard shunt (SS). Given the large number of patients that would be needed to definitively demonstrate superior efficacy of AISs over SSs in children, it is unlikely that a clinical trial will be conducted or is even needed.

\section{Acknowledgments}

We acknowledge the American Association of Neurological Surgeons (AANS)/Congress of Neurological Surgeons (CNS) Joint Guidelines Committee for the members' reviews, comments, and suggestions; Laura Mitchell, Guidelines Project Manager for the CNS, for her contributions; Pamela Shaw, research librarian, for her assistance with the literature searches; Kevin Boyer for his assistance with data analysis; and Sue Ann Kawecki and Kristin Kraus, M.Sc., for their assistance with editing.

\section{Disclosure}

The systematic review and evidence-based guidelines were funded exclusively by the CNS and AANS Pediatric Section, which received no funding from outside commercial sources to support the development of this document.

Conflict(s) of Interest: None. All Task Force members declared any potential conflicts of interest prior to beginning work on this evidence review.

Author contributions to the study and manuscript preparation include the following. Conception and design: AANS/CNS Joint Section on Pediatrics. Acquisition of data: all authors. Analysis and interpretation of data: all authors. Drafting the article: Klimo. Critically revising the article: all authors. Reviewed submitted version of manuscript: all authors. Approved the final version of the manuscript on behalf of all authors: Flannery. Statistical analysis: all authors. Administrative/technical/material support: all authors. Study supervision: Flannery. 


\section{References}

1. Albanese A, De Bonis P, Sabatino G, Capone G, Marchese E, Vignati A, et al: Antibiotic-impregnated ventriculo-peritoneal shunts in patients at high risk of infection. Acta Neurochir (Wien) 151:1259-1263, 2009

2. Aryan HE, Meltzer HS, Park MS, Bennett RL, Jandial R, Levy ML: Initial experience with antibiotic-impregnated silicone catheters for shunting of cerebrospinal fluid in children. Childs Nerv Syst 21:56-61, 2005

3. Attenello FJ, Garces-Ambrossi GL, Zaidi HA, Sciubba DM, Jallo GI: Hospital costs associated with shunt infections in patients receiving antibiotic-impregnated shunt catheters versus standard shunt catheters. Neurosurgery 66:284-289, 2010

4. Bayston R, Ashraf W, Bhundia C: Mode of action of an antimicrobial biomaterial for use in hydrocephalus shunts. J Antimicrob Chemother 53:778-782, 2004

5. Bayston R, Grove N, Siegel J, Lawellin D, Barsham S: Prevention of hydrocephalus shunt catheter colonisation in vitro by impregnation with antimicrobials. J Neurol Neurosurg Psychiatry 52:605-609, 1989

6. Bayston R, Lambert E: Duration of protective activity of cerebrospinal fluid shunt catheters impregnated with antimicrobial agents to prevent bacterial catheter-related infection. $\mathbf{J}$ Neurosurg 87:247-251, 1997

7. Borgbjerg BM, Gjerris F, Albeck MJ, Børgesen SE: Risk of infection after cerebrospinal fluid shunt: an analysis of 884 first-time shunts. Acta Neurochir (Wien) 136:1-7, 1995

8. Chadduck W, Adametz J: Incidence of seizures in patients with myelomeningocele: a multifactorial analysis. Surg Neurol 30:281-285, 1988

9. Choux M, Genitori L, Lang D, Lena G: Shunt implantation: reducing the incidence of shunt infection. J Neurosurg 77:875880,1992

10. Cochrane DD, Kestle JR: The influence of surgical operative experience on the duration of first ventriculoperitoneal shunt function and infection. Pediatr Neurosurg 38:295-301, 2003

11. Crowther M, Lim W, Crowther MA: Systematic review and meta-analysis methodology. Blood 116:3140-3146, 2010

12. Darouiche RO: Treatment of infections associated with surgical implants. N Engl J Med 350:1422-1429, 2004

13. Deeks JJ, Higgins JPT, Altman DG (eds): Analysing data and undertaking meta-analyses, in Higgins JPT, Green S (eds): Cochrane Handbook for Systematic Reviews of Interventions, Version 5.1.0. Cochrane Collaboration, 2011 [Accessed July 24, 2014]

14. DerSimonian R, Laird N: Meta-analysis in clinical trials. Control Clin Trials 7:177-188, 1986

15. Eymann R, Chehab S, Strowitzki M, Steudel WI, Kiefer M: Clinical and economic consequences of antibiotic-impregnated cerebrospinal fluid shunt catheters. J Neurosurg Pediatr 1:444-450, 2008

16. Eymann R, Steudel WI, Kiefer M: Infection rate with application of an antibiotic-impregnated catheter for shunt implantation in children - a retrospective analysis. Klin Padiatr 221:69-73, 2009

17. Farber SH, Parker SL, Adogwa O, McGirt MJ, Rigamonti D: Effect of antibiotic-impregnated shunts on infection rate in adult hydrocephalus: a single institution's experience. Neurosurgery 69:625-629, 2011

18. Farber SH, Parker SL, Adogwa O, Rigamonti D, McGirt MJ: Cost analysis of antibiotic-impregnated catheters in the treatment of hydrocephalus in adult patients. World Neurosurg 74:528-531, 2010

19. Govender ST, Nathoo N, van Dellen JR: Evaluation of an antibiotic-impregnated shunt system for the treatment of hydrocephalus. J Neurosurg 99:831-839, 2003

20. Gutiérrez-González R, Boto GR: Do antibiotic-impregnated catheters prevent infection in CSF diversion procedures? Review of the literature. J Infect 61:9-20, 2010

21. Gutiérrez-González R, Boto GR, Fernández-Pérez C, del Prado N: Protective effect of rifampicin and clindamycin impregnated devices against Staphylococcus spp. infection after cerebrospinal fluid diversion procedures. BMC Neurol 10:93, 2010

22. Haines SJ, Walters BC: Antibiotic prophylaxis for cerebrospinal fluid shunts: a metanalysis. Neurosurgery 34:87-92, 1994

23. Hayashi T, Shirane R, Kato T, Tominaga T: Efficacy of intraoperative wound irrigation for preventing shunt infection. $\mathbf{J}$ Neurosurg Pediatr 2:25-28, 2008

24. Hayhurst C, Cooke R, Williams D, Kandasamy J, O'Brien DF, Mallucci CL: The impact of antibiotic-impregnated catheters on shunt infection in children and neonates. Childs Nerv Syst 24:557-562, 2008

25. Horgan MA, Piatt JH Jr: Shaving of the scalp may increase the rate of infection in CSF shunt surgery. Pediatr Neurosurg 26:180-184, 1997

26. Jamjoom AB, Mohammed AA, al-Boukai A, Jamjoom ZA, Rahman N, Jamjoom HT: Multiloculated hydrocephalus related to cerebrospinal fluid shunt infection. Acta Neurochir (Wien) 138:714-719, 1996

27. Kan P, Kestle J: Lack of efficacy of antibiotic-impregnated shunt systems in preventing shunt infections in children. Childs Nerv Syst 23:773-777, 2007

28. Kandasamy J, Dwan K, Hartley JC, Jenkinson MD, Hayhurst C, Gatscher S, et al: Antibiotic-impregnated ventriculoperitoneal shunts-a multi-centre British paediatric neurosurgery group (BPNG) study using historical controls. Childs Nerv Syst 27:575-581, 2011

29. Kestle JR, Cochrane DD, Drake JM: Shunt insertion in the summer: is it safe? J Neurosurg 105 (3 Suppl):165-168, 2006

30. Kestle JR, Hoffman HJ, Soloniuk D, Humphreys RP, Drake JM, Hendrick EB: A concerted effort to prevent shunt infection. Childs Nerv Syst 9:163-165, 1993

31. Klimo P Jr, Thompson CJ, Ragel BT, Boop FA: Antibioticimpregnated shunt systems versus standard shunt systems: a meta- and cost-savings analysis. Clinical article. J Neurosurg Pediatr 8:600-612, 2011

32. Kontny U, Höfling B, Gutjahr P, Voth D, Schwarz M, Schmitt HJ: CSF shunt infections in children. Infection 21:89-92, 1993

33. Kulkarni AV, Drake JM, Lamberti-Pasculli M: Cerebrospinal fluid shunt infection: a prospective study of risk factors. J Neurosurg 94:195-201, 2001

34. Mapstone TB, Rekate HL, Nulsen FE, Dixon MS Jr, Glaser N, Jaffe M: Relationship of CSF shunting and IQ in children with myelomeningocele: a retrospective analysis. Childs Brain 11:112-118, 1984

35. Parker SL, Anderson WN, Lilienfeld S, Megerian JT, McGirt MJ: Cerebrospinal shunt infection in patients receiving antibiotic-impregnated versus standard shunts. A review. J Neurosurg Pediatr 8:259-265, 2011

36. Parker SL, Attenello FJ, Sciubba DM, Garces-Ambrossi GL, Ahn E, Weingart J, et al: Comparison of shunt infection incidence in high-risk subgroups receiving antibiotic-impregnated versus standard shunts. Childs Nerv Syst 25:77-83, 85, 2009

37. Pattavilakom A, Kotasnas D, Korman TM, Xenos C, Danks A: Duration of in vivo antimicrobial activity of antibioticimpregnated cerebrospinal fluid catheters. Neurosurgery 58:930-935, 2006

38. Pattavilakom A, Xenos C, Bradfield O, Danks RA: Reduction in shunt infection using antibiotic impregnated CSF shunt catheters: an Australian prospective study. J Clin Neurosci 14:526-531, 2007

39. Pirotte BJ, Lubansu A, Bruneau M, Loqa C, Van Cutsem N, Brotchi J: Sterile surgical technique for shunt placement reduces the shunt infection rate in children: preliminary analy- 


\section{Part 7: AIS systems versus conventional shunts in children}

sis of a prospective protocol in 115 consecutive procedures. Childs Nerv Syst 23:1251-1261, 2007

40. Ragel BT, Browd SR, Schmidt RH: Surgical shunt infection: significant reduction when using intraventricular and systemic antibiotic agents. J Neurosurg 105:242-247, 2006

41. Ratanalert S, Musikawat P, Oearsakul T, Saeheng S, Chowchuvech V: Non-shaved ventriculoperitoneal shunt in Thailand. J Clin Neurosci 12:147-149, 2005

42. Ratilal B, Costa J, Sampaio C: Antibiotic prophylaxis for surgical introduction of intracranial ventricular shunts: a systematic review. J Neurosurg Pediatr 1:48-56, 2008

43. Rehman AU, Rehman TU, Bashir HH, Gupta V: A simple method to reduce infection of ventriculoperitoneal shunts. Clinical article. J Neurosurg Pediatr 5:569-572, 2010

44. Richards HK, Seeley HM, Pickard JD: Efficacy of antibioticimpregnated shunt catheters in reducing shunt infection: data from the United Kingdom Shunt Registry. Clinical article. J Neurosurg Pediatr 4:389-393, 2009

45. Ritz R, Roser F, Morgalla M, Dietz K, Tatagiba M, Will BE: Do antibiotic-impregnated shunts in hydrocephalus therapy reduce the risk of infection? An observational study in 258 patients. BMC Infect Dis 7:38, 2007

46. Rozzelle CJ, Leonardo J, Li V: Antimicrobial suture wound closure for cerebrospinal fluid shunt surgery: a prospective, double-blinded, randomized controlled trial. J Neurosurg Pediatr 2:111-117, 2008

47. Sciubba DM, Lin LM, Woodworth GF, McGirt MJ, Carson B, Jallo GI: Factors contributing to the medical costs of cerebrospinal fluid shunt infection treatment in pediatric patients with standard shunt components compared with those in patients with antibiotic impregnated components. Neurosurg Focus 22(4):E9, 2007

48. Sciubba DM, McGirt MJ, Woodworth GF, Carson B, Jallo GI: Prolonged exposure to antibiotic-impregnated shunt catheters does not increase incidence of late shunt infections. Childs Nerv Syst 23:867-871, 2007

49. Sciubba DM, Noggle JC, Carson BS, Jallo GI: Antibiotic-impregnated shunt catheters for the treatment of infantile hydrocephalus. Pediatr Neurosurg 44:91-96, 2008
50. Sciubba DM, Stuart RM, McGirt MJ, Woodworth GF, Samdani A, Carson B, et al: Effect of antibiotic-impregnated shunt catheters in decreasing the incidence of shunt infection in the treatment of hydrocephalus. J Neurosurg 103 (2 Suppl):131-136, 2005

51. Steinbok P, Milner R, Agrawal D, Farace E, Leung GK, Ng I, et al: A multicenter multinational registry for assessing ventriculoperitoneal shunt infections for hydrocephalus. Neurosurgery 67:1303-1310, 2010

52. Stone J, Gruber TJ, Rozzelle CJ: Healthcare savings associated with reduced infection rates using antimicrobial suture wound closure for cerebrospinal fluid shunt procedures. Pediatr Neurosurg 46:19-24, 2010

53. Thomas R, Lee S, Patole S, Rao S: Antibiotic-impregnated catheters for the prevention of CSF shunt infections: a systematic review and meta-analysis. Br J Neurosurg 26:175-184, 2012

54. Vanaclocha V, Sáiz-Sapena N, Leiva J: Shunt malfunction in relation to shunt infection. Acta Neurochir (Wien) 138:829834, 1996

55. Walters BC, Hoffman HJ, Hendrick EB, Humphreys RP: Cerebrospinal fluid shunt infection. Influences on initial management and subsequent outcome. J Neurosurg 60:1014-1021, 1984

56. Zentner J, Gilsbach J, Felder T: Antibiotic prophylaxis in cerebrospinal fluid shunting: a prospective randomized trial in 129 patients. Neurosurg Rev 18:169-172, 1995

Manuscript submitted June 25, 2014.

Accepted July 7, 2014.

Please include this information when citing this paper: DOI: 10.3171/2014.7.PEDS14327.

Address correspondence to: Ann Marie Flannery, M.D., Department of Neurological Surgery, Saint Louis University, 3565 Vista Ave., St. Louis, MO 63110. email: flanneam@slu.edu. 